\title{
Enhancement of Lead Phytoremediation by Perennial Ryegrass (Lolium perenne L.) Using Agent of Streptomyces pactum Act12
} Shumiao Cao', Wenke Wang ${ }^{1 *}$, Yaqian Zhao ${ }^{2}$, Shenke Yang ${ }^{1}$, Fei Wang ${ }^{3}$, Jun Zhang ${ }^{1}$ and Yongchang Sun ${ }^{1}$ ${ }^{1}$ Key Laboratory of Subsurface Hydrology and Ecological Effects in Arid Region (Ministry of Education), School of Environment Science and Engineering, Chang'an University, Xi'an-710054, P.R. China

${ }^{2}$ Dooge Centre for Water Resources Research, School of Civil Engineering, University College Dublin, Belfield, Dublin, Ireland

${ }^{3}$ College of Science, Air Force Engineering University, Xi'an-710054, P.R. China

\begin{abstract}
It has been well recognized that microbes can assist phytoremediation of lead $(\mathrm{Pb})$ by promoting plant growth and metal uptake. However, little is known about the potential of soil inoculation with actinomycetes to enhance $\mathrm{Pb}$ uptake and translocation in plants, particularly in semi-arid water-deficient areas. This study was focused on exploring the resistance of a soil actinomycete strain (Streptomyces pactum Act12) to $\mathrm{Pb}$ and its effects on plant growth, antioxidant responses, $\mathrm{Pb}$ uptake and translocation in perennial ryegrass (Lolium perenne L.). Special attention was given to experimental conditions in semi-arid area in Northerwest China. A fermentation culture of Act12 was applied in powder form to soil with or without $\mathrm{Pb}$ treatment $\left(0-1,000 \mathrm{mg} \mathrm{kg}^{-1}\right)$, and ryegrass plants were immediately grown in this soil, in pots, for 60 days under $20 \%$ relative soil moisture. Act 12 showed tolerance to up to $1,200 \mathrm{mg} \mathrm{Pb} \mathrm{L}^{-1}$ in plate culture and well colonized the soil containing less than $500 \mathrm{mg} \mathrm{Pb} \mathrm{kg}^{-1}$. Under Pb stress, inoculated plants had higher biomass with greater plant height and root tiller number than the uninoculated controls. Additionally, higher catalase, superoxide dismutase and peroxidase activities were detected in leaves of inoculated plants under $\mathrm{Pb}$ stress. Inoculating soil with Act12 significantly increased $\mathrm{Pb}$ concentrations and uptake in plants grown in soil containing 200 to $1,000 \mathrm{mg} \mathrm{Pb} \mathrm{kg}^{-1}$. The translocation and bioconcentration factors of inoculated plants were $10.5-36.2 \%$ and $37.3-133.1 \%$ higher than uninoculated plants, respectively. Streptomyces pactum Act 12 can enhance $\mathrm{Pb}$ phytoremediation by perennial ryegrass and its powder form facilitates the use in semi-arid areas.
\end{abstract}

Keywords: Lead contamination; Phytoremediation; Microbial agent; Streptomyces pactum; Lolium perenne

\section{Introduction}

Lead $(\mathrm{Pb})$ is a major pollutant in contaminated soil under longterm sewage irrigation, abuse of fertilizer, and industrial activities [1,2]. Excessive $\mathrm{Pb}$ results in reduced soil fertility and health, affecting plant growth and leading to reduced crop production [3]. Moreover, $\mathrm{Pb}$ is the most toxic pollutants to living organisms and $\mathrm{Pb}$ exposure is related to the etiology of cardiovascular, renal, nervous, and blood diseases in human [4]. It is therefore crucial to develop effective measures for remediating $\mathrm{Pb}$-contaminated soils.

Phytoremediation is a low-cost, efficient, environmentally friendly method for eliminating toxic metals from soil. The process involves using metal-tolerant plants to extract contaminants from soil and to accumulate these contaminants in harvestable tissues [5]. Plants with great potential for metal phytoextraction include black nightshade (Solanum nigrum L.) [5], rape (Brassica napus L.) [6], and perennial ryegrass (Lolium perenne L.) [7]. However, slow plant growth, low biomass, and heavy-metal toxicity restrict the efficiency of phytoremediation $[8,9]$.

Microbes can assist in the process of phytoremediation by promoting plant growth and metal uptake from soil. The microbial mechanism of promoting plant growth is to facilitate phytohormone (e.g., indole acetic acid) and siderophore production, nitrogen fixation, minerals solubilization, and/or nutrient transformation in plants [10]. Additionally, microbes can increase the activity of antioxidant enzymes and the production of protective substances in plants, thereby protecting them from phytotoxic substances under metal stress and ultimately improving the efficiency of phytoremediation [11,12].

Plant-microbe interactions utilized in phytoremediation include mutually beneficial symbiotic associations of plants with growth- promoting bacteria and mycorrhizal fungi [13]. The available bacteria have been studied extensively under optimal laboratory conditions with $60 \%-80 \%$ relative soil moisture $[6,14]$. It is unclear whether inoculated plants can maintain an efficient phytoremediation of heavy metals in soil under water deficiency, e.g., $10 \%-30 \%$ relative soil moisture in extensive mainland of semi-arid areas in China $[15,16]$. Moreover, laboratory-cultivated bacteria or spore suspension has been frequently used for microbe-assisted phytoremediation. The liquid form of microbial agent was time-consuming to prepare and difficult to apply in large areas.

Actinomycetes have been reported less frequently than bacteria and mycorrhizal fungi to enhance $\mathrm{Pb}$ uptake and translocation in plants. For example, sorghum plants inoculated with Streptomyces mirabilis P16B1 exhibit increased growth and dry weight, suggesting that this strain may enhance phytoremediation by sorghum (Sorghum bicolor) [17]. A soil actinomycete strain, designated Streptomyces pactum Act12, was recently isolated from the Qinghai-Tibet Plateau [18], and S. pactum Act12 demonstrated beneficial effects on crop growth and resistance to plant diseases in pot experiments and field trials $[19,20]$. Given its

${ }^{*}$ Corresponding author: Wenke Wang, Key Laboratory of Subsurface Hydrology and Ecological Effects in Arid Region (Ministry of Education), School of Environment Science and Engineering, Chang'an University, China, Tel: +86 (29) 82339291 E-mail: wenkew@chd.edu.cn

Receive January 05, 2016; Accepted January 30, 2016; Published February 08 , 2016

Citation: Cao S, Wang W, Zhao Y, Yang S, Wang F, et al. (2016) Enhancement of Lead Phytoremediation by Perennial Ryegrass (Lolium perenne L.) Using Agent of Streptomyces pactum Act12. J Pet Environ Biotechnol 7: 269. doi:10.4172/2157 7463.1000269

Copyright: (c) 2016 Cao S, et al. This is an open-access article distributed under the terms of the Creative Commons Attribution License, which permits unrestricted use, distribution, and reproduction in any medium, provided the original author and source are credited. 
origin from an extreme environment (drought, low-temperature, highlatitude), it is hypothesized that $S$. pactum Act12 would increase the efficiency of $\mathrm{Pb}$ phytoremediation by plants under water deficiency in semi-arid regions.

In this study, pot experiments were conducted using perennial ryegrass (Lolium perenne L.), a cultivated perennial herbaceous plant capable of $\mathrm{Pb}$ uptake and transport from the soil [7]. The resistance of $S$. pactum Act 12 to $\mathrm{Pb}$ was examined and its effects on perennial ryegrass under $\mathrm{Pb}$ stress in a semi-arid area of natural water deficiency were then assessed. The study establishes an approach for actinomyceteassisted phytoremediation of $\mathrm{Pb}$-contaminated soil using a powder form of microbial agent, which may facilitate the use in water-deficient fields of arid or semi-arid areas.

\section{Materials and Methods}

\section{Soil, strain and plant}

Top soils of $0-30 \mathrm{~cm}$ in depth were sampled in a local farmland in Xi'an, Shaanxi Province, China $\left(34^{\circ} 09^{\prime} 24^{\prime \prime} \mathrm{N}, 108^{\circ} 56^{\prime} 36^{\prime \prime} \mathrm{E}\right)$. The soil represents a typical cinnamon soil in semi-arid area, Northwest China. Heavy metal contamination has occurred in the surface soil layer due to long-term irrational use of chemical fertilizers and pesticides [21], while the individual potential risk index of $\mathrm{Pb}$ content ranks the strong ecological hazard level [22]. After collection, the soil samples were air-dried, sieved using a 5-mm nylon sieve before physico-chemical characterization. The basic soil properties were organic matter of 14.57 $\mathrm{g} \mathrm{kg}^{-1}$, total nitrogen of $1.27 \mathrm{~g} \mathrm{~kg}^{-1}$, nitrate nitrogen of $14.43 \mathrm{mg} \mathrm{kg}$, total phosphorous of $0.49 \mathrm{~g} \mathrm{~kg}^{-1}$, olsen-phosphorous of $15.82 \mathrm{mg} \mathrm{kg}^{-1}$, total potassium of $240 \mathrm{mg} \mathrm{kg}^{-1}$, available potassium of $392.80 \mathrm{mg} \mathrm{kg}^{-1}$, $\mathrm{Pb}$ of $85.62 \mathrm{mg} \mathrm{kg}^{-1}$, zinc of $78.23 \mathrm{mg} \mathrm{kg}^{-1}$, bulk density of $1.21 \mathrm{~g} \mathrm{~cm}^{-3}$, $\mathrm{pH}$ of 6.77 (1:1 w/v water), and soil moisture of $20.56 \%$ (fresh soil).

Streptomyces pactum Act12 was provided by the Laboratory of Microbial Resources, College of Resources and Environment, Northwest A\&F University (Yangling, China) [18]. The agent Act12 was prepared by solid-state fermentation and applied in powder form $\left(5.3 \times 10^{10} \mathrm{CFU} \mathrm{g}^{-1}\right)$ [23]. The viable Act12 count was performed for colony forming units by the dilution-plate method on Gauze's No. 1 agar supplemented with antibiotics which were specific for the identification of actinomycete [24].

Perennial ryegrass (Lolium perenne L.) seeds were purchased from the Xin Nong Feng Agricultural Technology Research Institute (Beijing, China). Full-grain seeds of uniform size (1,000-grainweight: $2.2 \mathrm{~g}$ ) were surface-disinfected with $0.5 \% \mathrm{NaClO}$ solution $\left(10 \mathrm{~min}, 25^{\circ} \mathrm{C}\right)$ and thoroughly rinsed with distilled water before sowing.

\section{Pot experiments}

Dry soil sample was treated with $\mathrm{Pb}$ at five levels: 0, 200, 300, 500 and $1,000 \mathrm{mg} \mathrm{Pb} \mathrm{kg}{ }^{-1}$. A $\mathrm{Pb}$ solution was prepared by dissolving analytical-grade $\mathrm{Pb}\left(\mathrm{NO}_{3}\right)_{2}$ in distilled water. Soil moisture content was adjusted to approximate $20 \%$, close to the soil moisture content in natural farmland of semi-arid regions [25]. Prior to the experiment, $\mathrm{Pb}$-treated soil subsamples were kept in darkness at $20^{\circ} \mathrm{C}$ for 3 months to allow equilibrium to be reached between metal and soil.

Pot experiments were performed in two treatments: Act12 inoculation and non-inoculation. Each treatment with the five $\mathrm{Pb}$ concentrations had three replications respectively. Thirty plastic pots (diameter $23 \mathrm{~cm}$, depth $21 \mathrm{~cm}$ ) were filled with $\mathrm{Pb}$-treated soil using 3 kg per pot. For inoculation treatment, Act12 was pre-mixed with soil at $1.5 \mathrm{~g} \mathrm{~kg}^{-1}$ on a dry soil basis and placed into a pot. Non-inoculation treatment was prepared with $\mathrm{Pb}$-treated soil without Act12 and provided as the control.

Seeds were sown in 1-cm deep holes (50 seeds per pot) in late March. Three-week-old seedlings were thinned to 15 plants per pot and the pots were then randomly arranged in a plastic greenhouse. The plants were watered once per day to maintain approximately $20 \%$ soil moisture content. The growth conditions were recorded and plants were carefully harvested after $60 \mathrm{~d}$ of growth.

Rhizospere soil was removed from plant roots by gently shaking and collected for bacteria determination. Plant samples were washed with deionized water before measuring growth parameters including plant height, tiller number, and fresh weight. Ten gram of fresh leaf samples were excised and frozen in liquid nitrogen for physiochemical analysis. Plant roots and shoots were deactivated at $105^{\circ} \mathrm{C}$ for $30 \mathrm{~min}$, followed by heating at $80^{\circ} \mathrm{C}$ for $24 \mathrm{~h}$ for $\mathrm{Pb}$ analysis. Pot soils were dried and passed through a $0.075-\mathrm{mm}$ sieve and used to determine the bioavailable and residual $\mathrm{Pb}$ contents in the soil.

$\mathrm{Pb}$ tolerance analysis of actinomycetes strain: $\mathrm{Pb}$ resistance of $S$. pactum Act 12 was analyzed using phosphate-poor morphline propane sulfonic acid (MOPS) medium with $0.1 \%$ glucose as carbon source [26]. Act12 was streaked on MOPS agar plates containing gradient concentrations of $\mathrm{Pb}^{2+}$ from 0 to $1500 \mathrm{mg} \mathrm{L}^{-1}$ (100 mg L $\mathrm{L}^{-1}$ interval). The culture was incubated at $28^{\circ} \mathrm{C}$ for $7 \mathrm{~d}$. The minimum inhibitory concentration (MIC) of $\mathrm{Pb}$ was defined as the metal ion concentration that completely inhibited the growth of Act12 [6].

Sample analysis: Dry pot soil samples were ground in an agate mortar and digested in boiling aqua regia for $2 \mathrm{~h}$. The digested sample was adjusted to $50 \mathrm{~mL}$ with distilled water, before $\mathrm{Pb}$ analysis using the PerkinElmer Optima 5300DV ICP-OES system [27]. Bioavailable $\mathrm{Pb}$ in the soil was extracted by EDTA [27]. Dry plant samples were ground into a powder and digested in a mixture of $\mathrm{HNO}_{3}$ and $\mathrm{HClO}_{4}$ $(4: 1, \mathrm{v} / \mathrm{v}) . \mathrm{Pb}$ concentration in the digested sample was determined by ICP analysis [28].

Fresh leaves were cleaned and the leaf veins were removed. Leaf superoxide dismutase (SOD) activity was assayed using the nitroblue tetrazolium reduction method [29]. Catalase (CAT) activity was assayed by measuring the decomposition of hydrogen peroxide as reflected by the change of absorbance at $240 \mathrm{~nm}$ [30]. Peroxidase (POD) activity was analyzed in accordance with Polle et al. [31].

The number of viable Act12 in the rhizosphere soil was determined by serial dilution on MOPS plates containing $500 \mathrm{mg} \mathrm{L}^{-1} \mathrm{~Pb}$. The inoculated plates were incubated at $30^{\circ} \mathrm{C}$ for 7 days. With account taken of $\mathrm{Pb}$-resistant microorganisms and the appearance of characteristic colonies from the inoculated samples, only gray compact spiral colonies morphologically similar to colonies of Act 12 were considered as reisolates of Act12 [18].

Data analysis: For the parameters tested, rate of increase $(\Delta \mathrm{Ctrl} \%)$ was obtained as the percentage of the difference between Act12 inoculation and non-inoculation treatments to the non-inoculation control at the same $\mathrm{Pb}$ level. Translocation factor (TF) was calculated as the ratio of $\mathrm{Pb}$ concentration in shoots to that in roots. Bioconcentration factor (BCF) was calculated as the ratio of $\mathrm{Pb}$ concentration in plant (roots and shoots) to that in soil.

Average values of mean \pm SD $(n=3)$ are presented. Significance of difference between treatments was determined by DUNCAN test at $\alpha=0.05$. Statistical analysis was performed using SPSS 20.0 (IBM 
SPSS, Somers, NY, USA). An asterisk $\left(^{*}\right)$ denotes significant difference between Act12 inoculation and uninoculated control within the same soil $\mathrm{Pb}$ treatments $(P<0.05)$. Different lower-case letters indicate significant difference of Act12 inoculation or uninoculated control between different soil $\mathrm{Pb}$ treatments $(P<0.05)$.

\section{Results}

\section{Pb tolerance of Act12}

S. pactum Act12 demonstrated high $\mathrm{Pb}$ resistance in agar medium and the MIC of $\mathrm{Pb}$ to Act12 was up to $1,200 \mathrm{mg} \mathrm{L}^{-1}$. Plate culture results showed that the strain had good growth in the presence of $0-800 \mathrm{mg} \mathrm{Pb}$ $\mathrm{L}^{-1}$, while the growth was slower in the presence of $800-1,200 \mathrm{mg} \mathrm{Pb} \mathrm{L}^{-1}$.

After 60 days of cultivation in pots, Act12 was recovered from the rhizosphere of ryegrass plants with a high probability. Distinctive gray compact spiral colonies that morphologically resembled those of the original strain were considered as Act12 (Figure 1a). In the noninoculated soil samples, no colonies resembling Act12 were found. The maximum Act 12 count of the soil after 60 days of ryegrass growth was $5.45 \times 10^{7} \mathrm{CFU} \mathrm{g}^{-1}$ at $500 \mathrm{mg} \mathrm{Pb} \mathrm{kg}^{-1}$. The viable count of Act12 was reduced to a minimum of $0.90 \times 10^{7} \mathrm{CFU} \mathrm{g}^{-1}$ at $1,000 \mathrm{mg} \mathrm{Pb} \mathrm{kg}^{-1}$ (Figure 1d).

\section{Plant growth and biomass}

The growth of ryegrass plants was affected by $\mathrm{Pb}$ stress (Figure 2). As soil $\mathrm{Pb}$ level increased, plant height decreased in both inoculated and uninoculated treatments (Figure 1c); however, shoot fresh weight, root fresh weight, and tiller number initially increased before decreasing, with the maximum value at $300 \mathrm{mg} \mathrm{Pb} \mathrm{kg}^{-1}$.

Act12 inoculation had positive effects on the growth of ryegrass plants under $\mathrm{Pb}$ stress (Figure 2). Plant height, root fresh weight, and shoot fresh weight were significantly higher in inoculated plants than in the uninoculated controls, regardless of soil $\mathrm{Pb}$ level $(p<0.05)$. The greatest increases in plant height and root fresh weight were $12.3 \%$ and $94.6 \%$, at $300 \mathrm{mg} \mathrm{Pb} \mathrm{kg}^{-1}$, respectively. The maximum increase in shoot fresh weight was $29.6 \%$ at $1,000 \mathrm{mg} \mathrm{Pb} \mathrm{kg}{ }^{-1}$. Root tiller number significantly increased at all $\mathrm{Pb}$ levels except $500 \mathrm{mg} \mathrm{Pb} \mathrm{kg}^{-1}$; the greatest increase was $44.2 \%$ at $200 \mathrm{mg} \mathrm{Pb} \mathrm{kg}^{-1}$.

\section{Leaf antioxidant enzyme activity}

The leaf antioxidant enzyme activity in ryegrass plants was altered by the presence of $\mathrm{Pb}$ in soil (Table 1). As soil $\mathrm{Pb}$ level increased, leaf CAT and POD activities both decreased; however, SOD activity initially increased and peaked at $500 \mathrm{mg} \mathrm{Pb} \mathrm{kg}^{-1}$, followed by decreases.

Act12 inoculation positively affected leaf antioxidant enzyme activity in ryegrass plants (Table 1). Leaf CAT, SOD and POD activities were all higher in inoculated plants than in the uninoculated controls, regardless of $\mathrm{Pb}$ level, especially at high soil $\mathrm{Pb}$ levels (500 to 1,000 $\mathrm{mg} \mathrm{Pb} \mathrm{kg}{ }^{-1}$ ), where inoculated plants showed significantly increased enzyme activities $(p<0.05)$. The greatest increase in CAT and SOD activities were $70.3 \%$ and $58.4 \%$ at $1,000 \mathrm{mg} \mathrm{Pb} \mathrm{kg}^{-1}$, respectively, while a $94.2 \%$ increase in POD activity was observed at $500 \mathrm{mg} \mathrm{Pb} \mathrm{kg}^{-1}$.

\section{Lead bioavailability in soil and $\mathrm{Pb}$ accumulation and uptake in plants}

The bioavailable soil $\mathrm{Pb}$ content in pot soil without $\mathrm{Pb}$ treatment was $32.13 \pm 0.51 \mathrm{a} \mathrm{mg} \mathrm{kg}^{-1}$. Inoculation with Act 12 significantly increased bioavailable soil content (8.4-37.2\%) in a dose-dependent manner compared with the non-inoculation controls $(p<0.05)$ (Figure $1 b)$. The greatest increase in response to Act12 inoculation was observed at 500 $\mathrm{mg} \mathrm{Pb} \mathrm{kg}{ }^{-1}$ (Table 2).
$\mathrm{Pb}$ uptake and accumulation by ryegrass plants varied in a dosedependent manner. As soil $\mathrm{Pb}$ levels increased, there was an increase in root and shoot $\mathrm{Pb}$ concentrations and uptake in both inoculated and uninoculated plants. Act12 inoculation positively affected $\mathrm{Pb}$ uptake and accumulation under $\mathrm{Pb}$ stress. Both shoot and root $\mathrm{Pb}$ concentrations and uptakes were significantly higher in inoculated plants than in the uninoculated controls at 200 to $1,000 \mathrm{mg} \mathrm{Pb} \mathrm{kg}^{-1}$ $(p<0.05)$. For the inoculated plants, there were $61.7-130.4 \%$ (shoots) and $34.8-107.2 \%$ (roots) increases in $\mathrm{Pb}$ concentration, and 33.6$146.3 \%$ (shoots) and $36.4-173.4 \%$ (roots) increases in Pb uptake, compared with the uninoculated controls. The greatest increase in $\mathrm{Pb}$ concentrations and uptakes in response to Act12 inoculation was observed at $300 \mathrm{mg} \mathrm{Pb} \mathrm{kg}^{-1}$ (Table 2).

\section{Phytoremediation efficiency}

As soil $\mathrm{Pb}$ levels increased, TF decreased, while root $\mathrm{BCF}$ increased in both inoculated and uninoculated plants. Act12 inoculation promoted the translocation of $\mathrm{Pb}$ from roots to shoots, which resulted in a $10.5-36.2 \%$ increase in TF compared with the uninoculated control $(p<0.05)$. Meanwhile, inoculation with Act12 enhanced $\mathrm{Pb}$ absorption by roots and shoots from the soil, resulting in 37.3-109.4\% increase in root BCF and 62.7-133.1\% increase in shoot BCF $(p<0.05)$. The greatest increase in TF was observed at $500 \mathrm{mg} \mathrm{Pb} \mathrm{kg}^{-1}$, while the greatest increases in root BCF and shoot BCF were observed at $300 \mathrm{mg}$ $\mathrm{Pb} \mathrm{kg}^{-1}$ (Table 3).

\section{Discussion}

\section{The role of $S$. pactum Act12}

Microbes isolated from extreme environments provide a potential source for phytoremediation in contaminated soils under adverse conditions. Strain Act12 was isolated from a unique environment (drought, low-temperature, and high-latitude) on the Qinghai-Tibet Plateau [18]. Owing to the long-term adaption, Act12 may have evolved versatile mechanisms to cope with adverse stress. In the present study, Streptomyces pactum Act12 demonstrated high resistance to $\mathrm{Pb}$ (MIC $=1,200 \mathrm{mg} \mathrm{Pb} \mathrm{L}^{-1}$ ) in plate culture. As has been reported [32], processes of biosorption, reduction, biomineralization, extracellular binding by chelators, efflux by transport systems, and/or intracellular binding of metals are all involving as the role of Streptomycetes.

The rhizosphere, as an interface of soil and plant, supplies a niche for metal-tolerant bacteria that are essential for promoting plant-growth activities, alleviating plant stress and mobilizing or immobilizing metals [33]. Pot experiments showed that Act12 well colonized the soil containing less than $500 \mathrm{mg} \mathrm{Pb} \mathrm{kg}^{-1}$ and suffered a certain degree of inhibition at $1,000 \mathrm{mg} \mathrm{Pb} \mathrm{kg}^{-1}$ under $20 \%$ relative soil moisture, in agreement with the results of plate culture analysis for $\mathrm{Pb}$ tolerance. Taken together, the above results indicate that $S$. pactum Act 12 is resistant to $\mathrm{Pb}$ and can thrive in soil with relatively low water content. This strain exhibits great potential for agricultural use in semiarid regions.

It has been noted that low plant biomass could be a bottleneck in phytoremediation of heavy metal-contaminated soils [8]. Thus, plant-growth-promoting and heavy-metal-tolerant microbes are preferentially used to improve the efficiency of phytoextraction $[12,14]$. In the present study, S. pactum Act12 demonstrated plant-growthpromoting effects on ryegrass plants under $\mathrm{Pb}$ stress, as indicated by the greater root tiller number plant height and biomass (Figure 2). This is consistent with the results observed in cotton and ginseng [20,34]. The effect of Act 12 may be related to the production of indole-3-acetic acid, 
Citation: Cao S, Wang W, Zhao Y, Yang S, Wang F, et al. (2016) Enhancement of Lead Phytoremediation by Perennial Ryegrass (Lolium perenne L.) Using Agent of Streptomyces pactum Act12. J Pet Environ Biotechnol 7: 269. doi:10.4172/2157-7463.1000269

Page 4 of 7

\begin{tabular}{|c|c|c|c|c|}
\hline \multicolumn{2}{|c|}{$\mathrm{Pb}$ treatment $\left(\mathrm{mg} \mathrm{kg}^{-1}\right)$} & \multirow{2}{*}{$\begin{array}{c}\text { CAT } \cup \mathrm{g}^{-1} \mathrm{~min}^{-1} \\
2.63 \pm 0.13\end{array}$} & \multirow{2}{*}{$\begin{array}{c}\text { SOD } \mathrm{U} \mathrm{g}^{-1} \mathrm{FW} \\
80.70 \pm 5.72\end{array}$} & \multirow{2}{*}{$\begin{array}{c}\text { POD U mg }{ }^{-1} \mathrm{~min}^{-1} \\
113.25 \pm 7.11\end{array}$} \\
\hline \multirow{3}{*}{0} & Control & & & \\
\hline & Act12 & $3.14 \pm 0.14$ & $85.70 \pm 4.41$ & $146.02 \pm 5.38$ \\
\hline & $\Delta \mathrm{Ctrl}(\%)$ & $19.3^{*}$ & 6.2 & $16.8^{*}$ \\
\hline \multirow{3}{*}{200} & Control & $2.48 \pm 0.23$ & $95.69 \pm 4.17$ & $107.35 \pm 3.72$ \\
\hline & Act12 & $2.57 \pm 0.22$ & $104.22 \pm 2.92$ & $113.25 \pm 7.05$ \\
\hline & $\Delta \mathrm{Ctrl}(\%)$ & 3.6 & $8.9^{*}$ & 5.5 \\
\hline \multirow{3}{*}{300} & Control & $2.33 \pm 0.19$ & $107.35 \pm 5.72$ & $94.22 \pm 1.86$ \\
\hline & Act12 & $2.77 \pm 0.12$ & $113.82 \pm 4.64$ & $115.69 \pm 8.65$ \\
\hline & $\Delta \mathrm{Ctrl}(\%)$ & $19.0^{*}$ & 6.0 & $22.8^{*}$ \\
\hline \multirow{3}{*}{500} & Control & $1.55 \pm 0.24$ & $135.05 \pm 6.62$ & $67.70 \pm 3.52$ \\
\hline & Act12 & $2.52 \pm 0.10$ & $176.02 \pm 6.63$ & $131.49 \pm 7.70$ \\
\hline & $\Delta \mathrm{Ctrl}(\%)$ & $62.4^{*}$ & $30.3^{*}$ & $94.2^{*}$ \\
\hline \multirow{3}{*}{1,000} & Control & $1.38 \pm 0.25$ & $71.49 \pm 5.40$ & $62.67 \pm 2.34$ \\
\hline & Act12 & $2.35 \pm 0.21$ & $113.25 \pm 7.11$ & $89.82 \pm 4.87$ \\
\hline & $\Delta \mathrm{Ctrl}(\%)$ & $70.3^{*}$ & $58.4^{*}$ & $43.3^{*}$ \\
\hline
\end{tabular}

Table 1: Leaf antioxidant enzyme activity (catalase activity, CAT; superoxide dismutase, SOD; peroxidase activity, POD.) of perennial ryegrass in Pb-treated soil inoculated with or without Streptomyces pactum Act12 (means $\pm \mathrm{SD}, n=3$ ).

\begin{tabular}{|c|c|c|c|c|c|c|}
\hline \multicolumn{2}{|c|}{$\mathrm{Pb}$ treatment $\left(\mathrm{mg} \mathrm{kg}^{-1}\right)$} & \multicolumn{2}{|c|}{$\mathrm{Pb}$ concentration $\left(\mathrm{mg} \mathrm{kg}^{-1}\right)$} & \multicolumn{2}{|c|}{ Pb uptake $\left(\mu\right.$ pot $\left.^{-1}\right)$} & \multirow{2}{*}{$\begin{array}{c}\text { Bioavailable soil } \mathrm{Pb}(\mathrm{mg} \\
\left.\mathrm{kg}^{-1}\right)\end{array}$} \\
\hline & & Shoot & Root & Shoot & Root & \\
\hline \multirow[t]{3}{*}{0} & Control & $1.53 \pm 0.13$ & $6.35 \pm 0.48$ & $31.71 \pm 3.89$ & $50.23 \pm 3.69$ & $32.13 \pm 0.51$ \\
\hline & Act12 & $1.61 \pm 0.17$ & $6.51 \pm 0.82$ & $35.44 \pm 2.90$ & $57.15 \pm 3.51$ & $34.84 \pm 1.09$ \\
\hline & $\Delta \mathrm{Ctrl}(\%)$ & 5.0 & 2.5 & 11.8 & 13.8 & $8.4^{*}$ \\
\hline \multirow[t]{3}{*}{200} & Control & $5.49 \pm 0.46$ & $19.70 \pm 1.59$ & $131.34 \pm 16.95$ & $157.45 \pm 15.93$ & $73.39 \pm 3.26$ \\
\hline & Act12 & $8.88 \pm 0.86$ & $26.51 \pm 2.16$ & $174.45 \pm 13.95$ & $311.98 \pm 35.27$ & $85.32 \pm 2.93$ \\
\hline & $\Delta \mathrm{Ctrl}(\%)$ & $61.7^{*}$ & $34.8^{*}$ & $33.6^{*}$ & $98.1^{*}$ & $16.3^{*}$ \\
\hline \multirow[t]{3}{*}{300} & Control & $6.01 \pm 0.52$ & $27.27 \pm 2.57$ & $152.65 \pm 12.34$ & $306.29 \pm 23.16$ & $123.98 \pm 8.95$ \\
\hline & Act12 & $13.86 \pm 1.14$ & $56.51 \pm 5.89$ & $376.02 \pm 29.18$ & $837.42 \pm 67.95$ & $165.86 \pm 3.99$ \\
\hline & $\Delta \mathrm{Ctrl}(\%)$ & $130.4^{*}$ & $107.2^{*}$ & $146.3^{*}$ & $173.4^{*}$ & $33.8^{*}$ \\
\hline \multirow[t]{3}{*}{500} & Control & $9.16 \pm 0.82$ & $63.25 \pm 5.26$ & $281.56 \pm 12.40$ & $876.86 \pm 106.84$ & $231.06 \pm 22.33$ \\
\hline & Act12 & $17.12 \pm 1.33$ & $86.83 \pm 6.93$ & $423.68 \pm 35.63$ & $1195.69 \pm 112.15$ & $317.05 \pm 2.88$ \\
\hline & $\Delta \mathrm{Ctrl}(\%)$ & $86.9^{*}$ & $37.3^{*}$ & $50.5^{\star}$ & $36.4^{*}$ & $37.2^{*}$ \\
\hline \multirow[t]{3}{*}{1,000} & Control & $21.88 \pm 2.04$ & $133.51 \pm 14.31$ & $540.94 \pm 31.40$ & $1682.01 \pm 98.57$ & $370.87 \pm 11.76$ \\
\hline & Act12 & $36.45 \pm 2.65$ & $201.10 \pm 15.12$ & $1178.72 \pm 110.24$ & $2530.10 \pm 231.38$ & $418.71 \pm 16.33$ \\
\hline & $\Delta \mathrm{Ctrl}(\%)$ & $66.6^{*}$ & $50.6^{*}$ & $117.9^{*}$ & $50.4^{*}$ & $13.1^{*}$ \\
\hline
\end{tabular}

Table 2: $\mathrm{Pb}$ concentration and uptake in perennial ryegrass plants, and bioavailable soil $\mathrm{Pb}$ in Pb-treated soil inoculated with or without Streptomyces pactum Act12 (means $\pm \mathrm{SD}, n=3)$.

\begin{tabular}{|c|c|c|c|c|c|c|c|c|c|}
\hline \multirow{2}{*}{$\begin{array}{l}\mathrm{Pb} \text { treatment } \\
\left(\mathrm{mg} \mathrm{kg}^{-1}\right)\end{array}$} & \multicolumn{3}{|c|}{ TF (\%) } & \multicolumn{3}{|c|}{ Root BCF (\%) } & \multicolumn{3}{|c|}{ Shoot BCF (\%) } \\
\hline & Control & Act12 & $\begin{array}{c}\Delta \text { Ctrl } \\
(\%)\end{array}$ & Control & Act12 & $\begin{array}{c}\text { RegularCtrl } \\
(\%)\end{array}$ & Control & Act12 & $\begin{array}{c}\text { RegularCtr } \\
(\%)\end{array}$ \\
\hline 0 & $24.11 \pm 1.45$ & $24.76 \pm 1.61$ & 2.7 & $7.55 \pm 0.20$ & $7.72 \pm 0.26$ & 2.3 & $1.82 \pm 0.11$ & $1.91 \pm 0.1$ & 5.0 \\
\hline 200 & $27.91 \pm 0.09$ & $33.45 \pm 0.51$ & $19.9^{*}$ & $6.97 \pm 0.12$ & $9.46 \pm 0.03$ & $35.8^{*}$ & $1.94 \pm 0.03$ & $3.16 \pm 0.04$ & $62.7^{*}$ \\
\hline 300 & $22.06 \pm 0.2$ & $24.56 \pm 0.57$ & $11.3^{*}$ & $7.16 \pm 0.05$ & $14.99 \pm 0.09$ & $109.4^{*}$ & $1.58 \pm 0.01$ & $3.68 \pm 0.1$ & 133.1* \\
\hline 500 & $14.47 \pm 0.17$ & $19.72 \pm 0.18$ & $36.2^{*}$ & $11.00 \pm 0.10$ & $15.10 \pm 0.18$ & $37.3^{*}$ & $1.59 \pm 0.02$ & $2.98 \pm 0.04$ & $87.0^{*}$ \\
\hline 1,000 & $16.4 \pm 0.24$ & $18.13 \pm 0.07$ & $10.5^{*}$ & $12.43 \pm 0.33$ & $18.86 \pm 0.15$ & $51.7^{*}$ & $2.04 \pm 0.02$ & $3.42 \pm 0.03$ & $67.7^{*}$ \\
\hline
\end{tabular}

Table 3: Average translocation factor (TF) and bioaccumulation coefficient (BCF) of perennial ryegrass plants in Pb-treated soil inoculated with or without Streptomyces pactum Act12 (means $\pm \mathrm{SD}, \mathrm{n}=3$ ).

siderophores and 1-aminocyclopropane-1-carboxylic acid deaminase, and/or solubilization of inorganic phosphate [6,12]. Additionally, metabolites such as organic acids, amino acids, and vitamins, as well as extracellular hydrolytic enzymes produced by branched mycelia [35], can stimulate root uptake of nutrients and subsequent plant growth. Moreover, actinomycetes are beneficial to rhizosphere soil microflora and thus could indirectly contribute to plant growth [20].

The plant growth-promoting effect of Act12 observed in the current study was more significant in soil at higher $\mathrm{Pb}$ levels. Similar results have been observed in Streptomyces mirabilis P16B-1, which promotes the growth of $S$. bicolor in a dose-dependent manner [17]. A combination of mycorrhiza and Streptomycetes also achieves a slight, albeit statistically significant increase in the biomass productivity of the same plant [36]. Previous studies have added the microbes as cell suspensions after laboratory cultivation for days and used them in soil under optimal water conditions $(60 \%-80 \%)$. In the present study, Act12 was applied in powder form, which is convenient for preservation, maintenance of high activity, and application in large fields. With respect of soil condition, Act12 was tested in soil with $20 \%$ relative water content. This condition reflects the actual water status 

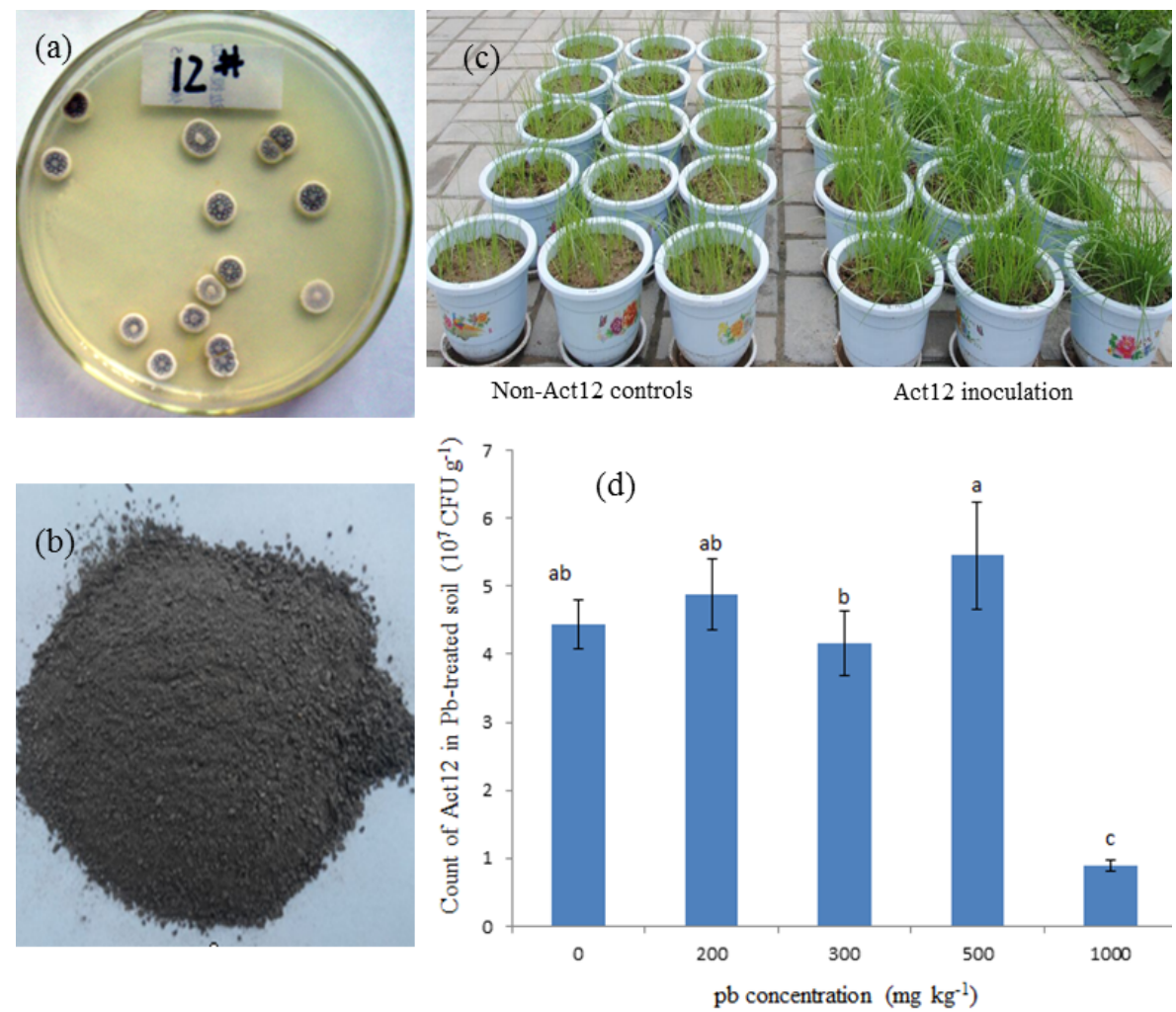

Figure 1: Streptomyces pactum Act12 colonies (a), powder form agent (b), the growth of perennial ryegrass plants in Pb-treated soil with or without Act12 inoculation (c) and the count of Streptomyces pactum Act12 after 60-d survival in Pb-treated rhizosphere soil with or without inoculation. (means \pm SD, $n=3$ ).
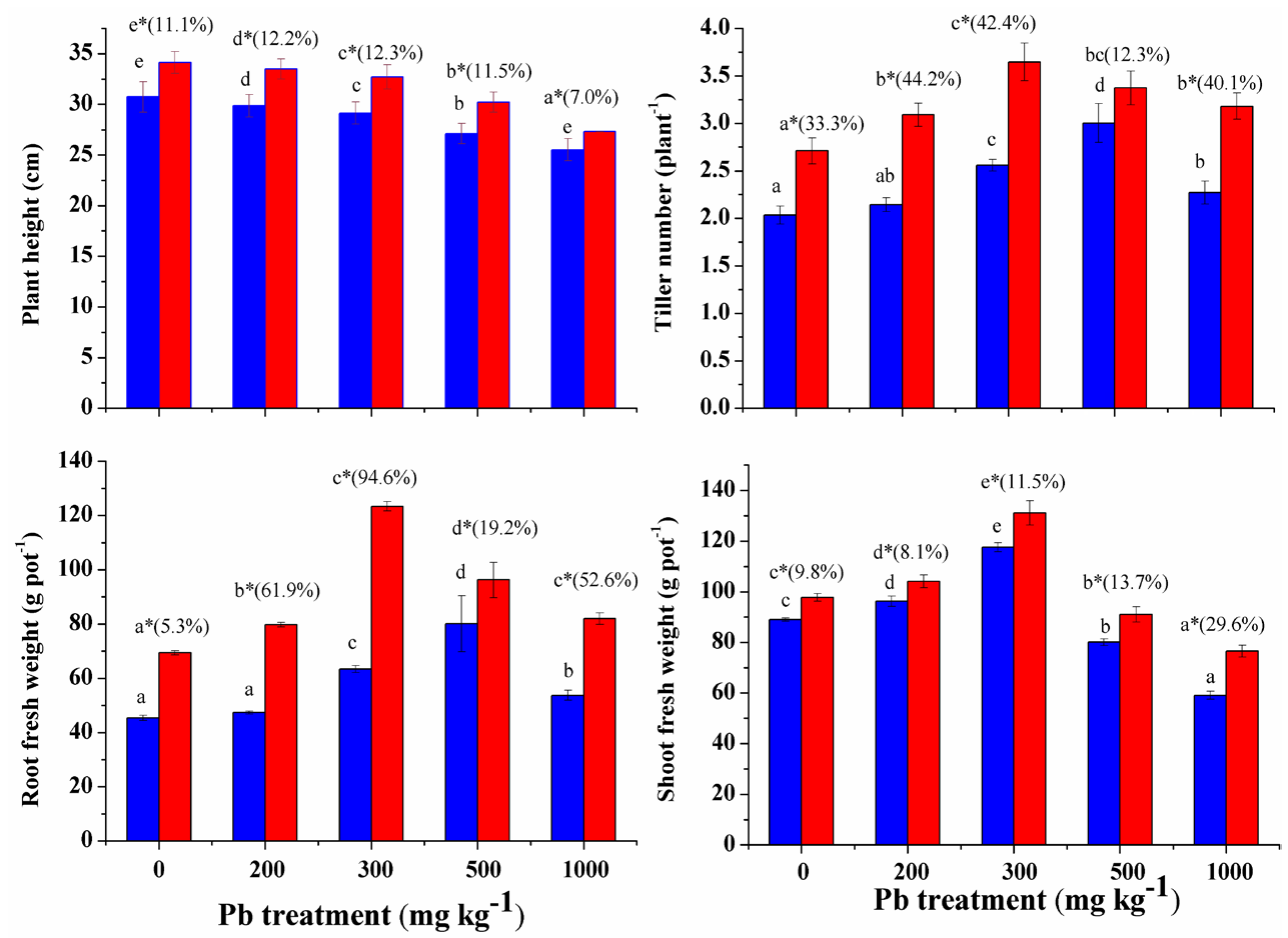

Perennial ryegrass

Perennial ryegrass-Act12

Figure 2: Growth parameters ofperennial ryegrassin Pb-treated soil inoculated with or without Streptomyces pactumAct12 (a), plant height (b), tiller number (c), root fresh weight and (d) shoot fresh weightofperennial ryegrass after 60 -d survival. (means $\pm S D, n=3$ ). 
in semi-arid water-deficient areas. Therefore, the powder form of Act12 will facilitate the use in heavy metal remediation across semi-arid regions.

In addition, lead can produce physiological stress and induce the production of superoxide anion $\left(\mathrm{O}_{2} \cdot-\right)$ and hydrogen peroxide $\left(\mathrm{H}_{2} \mathrm{O}_{2}\right)$ in perennial ryegrass [30], which are harmful to plant cells. Plants can produce antioxidant enzymes to reduce the oxidative stress and maintain the resistance against heavy metals [37]. The current results show that soil inoculation with strain Act12 increased leaf CAT, SOD and $\mathrm{POD}$ activities in ryegrass plants under $\mathrm{Pb}$ stress compared with the un inoculated control. The activities of the three enzymes markedly increased in inoculated plants grown in soil at higher Pb levels (500$\left.1,000 \mathrm{mg} \mathrm{kg}^{-1}\right)$. SOD can convert active and toxic superoxide radical into $\mathrm{H}_{2} \mathrm{O}_{2}$; CAT and POD then eliminate $\mathrm{H}_{2} \mathrm{O}_{2}$ through the conversion to $\mathrm{H}_{2} \mathrm{O}$ and $\mathrm{O}_{2}$ [37]. Improving the antioxidant enzyme activity thus can increase the detoxification of heavy metal stress by plants [38].

At the cellular level, high levels of $\mathrm{Pb}$ in plants can pose phytotoxic effects by inducing excessive accumulation of reactive oxygen species. Act12 in the rhizospheric microbial communities might enhance the tolerance of ryegrass plants against $\mathrm{Pb}$ toxicity by producing plant growth-promoting factors such as indole acetic acid (IAA), siderophores, 1-aminocyclopropane-1-carboxylate (ACC) deaminase $[39,40]$. Additionally, Act12 might produce organic acids and amino acids that are high-affinity ligands for the chelation of $\mathrm{Pb}$ by cytosol. This mechanism could lower ionic $\mathrm{Pb}$ in cytoplasm, attenuate the phytotoxic effect, and then normalize the antioxidative response of plants, ultimately contributing to metal detoxification and tolerance [13,41].

Similarly, co-inoculation of lentil with $\mathrm{Pb}$-resistant bacteria $(A$. tumefaciens, R. aquatilis, and Pseudomonas sp.) increases CAT, SOD, and POD activities in plants under $\mathrm{Pb}$ stress [42]. An endophytic fungus (EF0801) benefits rice growth under moderate $\mathrm{Pb}$ stress by enhancing CAT, SOD, and POD and reducing MDA levels [12]. A recent study has reported that the expression of genes encoding antioxidant enzymes is upregulated in plants to help alleviate metal toxicity [11]. These findings confirm that Act12 can enhance the tolerance of perennial ryegrass to $\mathrm{Pb}$ stress by enhancing antioxidant enzyme activities. This can be regarded as a defense mechanism against $\mathrm{Pb}$ toxicity, and thus beneficial to plant growth.

Furthermore, phytoextraction capacity is influenced by metal accumulation in plant tissues and biomass productivity [38]. The present study showed that Act12 inoculation increased $\mathrm{Pb}$ bioavailability in the contaminated soil and improved $\mathrm{Pb}$ concentrations and uptake in shoots and roots of perennial ryegrass plants under $\mathrm{Pb}$ stress (Table 2). Microbes can alter metal availability and mobility to the plant by acidification, chelation and oxidation-reduction reactions in the rhizosphere [43], ultimately contributing to metal accumulation in plants. Similarly, an endophytic Rahnella sp. JN6 was reported to increase the availability of $\mathrm{Pb}$ in soil and enhance $\mathrm{Pb}$ uptake by B. napus [6].

In the $300 \mathrm{mg} \mathrm{kg}^{-1}$ soil treatment, the $\mathrm{Pb}$ concentrations and uptake in Act12-inoculated plant showed greater than 100\% increase relative to those in the uninoculated controls. The effect of Act12 is markedly stronger than that of the rhizobacterium Burkholderia sp. D54 (PGPR) in increasing $\mathrm{Pb}$ levels in ryegrass $(11.3 \%$ increase in roots, no effects in shoots) [14]. Streptomycete can produce versatile secondary metabolites such as organic acids which were cosidered as the sources of protons for mobilization and metal-chelating anions to form complexes with metal cations $[44,45]$.

The TF and BCF are two indices used to assess the efficiency of phytoremediation in $\mathrm{Pb}$-contaminated soil [7]. The TF was less than 1.0 in ryegrass plants, as $\mathrm{Pb}$ is more likely to be absorbed and accumulate in roots than in shoots [30]. When we inoculated strain Act12 into Pbtreated soil, there were greater $\mathrm{TF}$ and $\mathrm{BCF}$ of $\mathrm{Pb}$ in both the roots and shoots of ryegrass plants than in the uninoculated control. This result suggested that soil inoculation with Act12 can promote the translocation of $\mathrm{Pb}$ from roots to shoots and boost $\mathrm{Pb}$ absorption by ryegrass plants from the soil. The current findings confirm that strain Act12 can improve the phytoremediation efficiency of perennial ryegrass.

\section{Prospects of lead phytoremediation in arid and semi-arid areas}

A number of studies claimed that lead phytoremediation can be enhanced by the assistance of beneficial bacteria $[6,1,36]$. These bacteria improve plant growth and increase plant biomass, in turn assisting phytoremediation by its growth-promoting traits. In addition, microbes can protect plants from phytotoxic substances under lead stress by increasing the activity of antioxidant enzymes and the production of protective substances in plants. Additionally, lead uptake can be promoted by the transformation of lead into bioavailable and soluble forms through the action of bacteria. However, in arid and semi-arid area, the application of lead phytoremediation should pay special attention to the restriction of water deficiency as drought stress could result in low biomass production, low rates of metal removal and insufficiently metal uptake into plant tissue [46]. More significantly, the effective plant microbial remediation technologies suitable for $\mathrm{Pb}$-contaminated soil in the arid and semi-arid area are not properly documented in the literature. This study has demonstrated that actinomycetes could assist $\mathrm{Pb}$ phytoremediation under water deficiency. It is reasonable to believe that the findings of this study will promote the further studies and potential application of $\mathrm{Pb}$ control in arid and semiarid areas, especially in China as it has $3.07 \times 10^{6} \mathrm{~km}^{2}$ in Northwest China while most of the areas are reported to be polluted during the last two decades of the industrialization/urbanization $[1,2,21]$.

\section{Conclusions}

Streptomycetes pactum Act12 exhibited high $\mathrm{Pb}$ tolerance and colonized the rhizosphere containing a wide range of $\mathrm{Pb}$. Soil inoculation with Act12 in powder form promoted plant growth and enhanced $\mathrm{Pb}$ tolerance in ryegrass grown in $\mathrm{Pb}$-treated soil in a semi-arid area of natural water deficiency by increasing antioxidant enzyme activities. Meanwhile, Act12 improved the bioavailability of $\mathrm{Pb}$ in the soil and improved $\mathrm{Pb}$ accumulation and uptake by ryegrass, achieving high bioconcentration and phytoremediation efficiency. S. pactum Act12 represents $\mathrm{Pb}$-resistant microbial agent that can be used in phytoremediation in semi-arid water-deficient areas. The powder form of Act12 guarantees its convenience for transport and application. Field trials will be conducted to assess the effects of Act12 on phytoremediation and reveal its protective mechanisms under drought conditions.

\section{Acknowledgment}

This study was supported by the Key Program of National Natural Science Foundation of China (41230314), the program for Changjiang Scholars and Innovative Research Team of the Chinese Ministry of Education (IRT0811), the Open Fund of Engineering Research Center of Groundwater and Eco-Environment of Shaanxi Province (310829151146), and the Key Laboratory of Subsurface Hydrology and Ecological Effect in Arid Region, Ministry of Education of the People's Republic of China. 
Citation: Cao S, Wang W, Zhao Y, Yang S, Wang F, et al. (2016) Enhancement of Lead Phytoremediation by Perennial Ryegrass (Lolium perenne L.) Using Agent of Streptomyces pactum Act12. J Pet Environ Biotechnol 7: 269. doi:10.4172/2157-7463.1000269

\section{References}

1. Nan ZR, Zhao CY (2000) Heavy metal concentrations in gray calcareous soils of Baiyin region, Gansu province, PR China. Water, Air, and Soil Pollution 118: $131-142$

2. Wei B, Jiang F, Li X, Mu S (2010) Heavy metal induced ecological risk in the city of Urumqi, NW China. Environ Monit Assess 160: 33-45.

3. Hassan W, Bano R, Bashir F, David J (2014) Comparative effectiveness of ACCdeaminase and/or nitrogen-fixing rhizobacteria in promotion of maize (Zea mays L.) growth under lead pollution. Environ Sci Pollut Res Int 21: 10983-10996.

4. Järup L (2003) Hazards of heavy metal contamination. Br Med Bull 68: 167-182.

5. Yu CL, Peng XL, Yan H, Li XX, Zhou ZH, Yan TL (2015) Phytoremediation Ability of Solanum nigrum L. to Cd-Contaminated Soils with High Levels of $\mathrm{Cu}$ $\mathrm{Zn}$, and Pb. Water, Air, \& Soil Pollution 226: 1-10.

6. He H, Ye Z, Yang D, Yan J, Xiao L, et al. (2013) Characterization of endophytic Rahnella sp. JN6 from Polygonum pubescens and its potential in promoting growth and $\mathrm{Cd}, \mathrm{Pb}, \mathrm{Zn}$ uptake by Brassica napus. Chemosphere 90: 1960-1965.

7. Lou Y, Luo H, Hu T, Li H, Fu J (2013) Toxic effects, uptake, and translocation of $\mathrm{Cd}$ and $\mathrm{Pb}$ in perennial ryegrass. Ecotoxicology 22: 207-214.

8. Komárek M, Tlustos P, Száková J, Chrastný V, Ettler V (2007) The use of maize and poplar in chelant-enhanced phytoextraction of lead from contaminated agricultural soils. Chemosphere 67: 640-651.

9. Srivastava D, Singh A, Baunthiyal M (2015) Lead Toxicity and Tolerance in Plants. Journal of Plant Science \& Research 2: 2349-2850.

10. Glick BR (2003) Phytoremediation: synergistic use of plants and bacteria to clean up the environment. Biotechnol Adv 21: 383-393.

11. Kong ZY, Mohamad OA, Deng ZS, Liu XD, Glick BR, et al. (2015) Rhizobial symbiosis effect on the growth, metal uptake, and antioxidant responses of Medicago lupulina under copper stress. Environmental Science and Pollution Research 22: 12479-12489.

12. Li X, Bu N, Li Y, Ma L, Xin S, et al. (2012) Growth, photosynthesis and antioxidant responses of endophyte infected and non-infected rice under lead stress conditions. J Hazard Mater 213-214: 55-61.

13. Gupta DK, Huang HG, Corpas FJ (2013) Lead tolerance in plants: strategies for phytoremediation. Environ Sci Pollut Res Int 20: 2150-2161.

14. Guo JK, Chi J (2014) Effect of Cd-tolerant plant growth-promoting rhizobium on plant growth and Cd uptake by Lolium multiflorum Lam. and Glycine max (L.) Merr. in Cd-contaminated soil. Plant Soil 375: 205-214.

15. Guan X, Huang J, Guo N, Bi J, Wang G (2009) Variability of soil moisture and its relationship with surface albedo and soil thermal parameters over the Loess Plateau. Advances in Atmospheric Sciences 26: 692-700.

16. Li MX, Ma ZG (2015) Soil moisture drought detection and multi-tempora variability across China. Science China Earth Sciences 58: 1798-1813.

17. Schütze E, Klose M, Merten D, Nietzsche S, Senftleben D, et al. (2014) Growth of streptomycetes in soil and their impact on bioremediation. J Hazard Mater 267: 128-135.

18. Zhao J, Xue QH, Wang LN, Duan CM, Xue L, Mao N (2011) Antagonistic effect of multifunctional actinomycete strain Act12 on soil-borne pathogenic fungi and its identification. Chinese Journal of Eco-Agriculture 19: 394-398.

19. He F, Zhang ZL, Cui M, Xue QH, Wang DS (2015) Disease prevention and growth promotion effects of actinomycete strain D74 on Amorphophallus konjac. Acta Horticulturae Sinica 42: 367-376.

20. Zhang HY, Xue QH, Shen GH, Wang DS (2013) [Effects of actinomycetes agent on ginseng growth and rhizosphere soil microflora]. Ying Yong Sheng Tai Xue Bao 24: 2287-2293.

21. Zheng GZ, Yue LP, Li ZP, Chen C (2006) Assessment on heavy metals pollution of agricultural soil in Guanzhong District. Journal of Geographical Sciences 16: 105-113.

22. Zhang J (2010) Heavy metal accumulation and quality evaluation of soils in the Chang'an District of Xi'an, China. Master thesis, Shaanxi Normal University.

23. Xue QH, Cai Y, Si MR, Tu X, Chen ZQ, et al. (2004) Preparation for biological prevention and cure of hot pepper epidemic disease and method for producing the same. Northwest Agriculture and Forestry University and Create Microbial Engineering Institute, Yangling, China. Patent CN100334953C

24. Xue L, Xue QH, Chen Q, Lin C, Shen GH, Zhao J (2013) Isolation and evaluation of rhizosphere actinomycetes with potential application for biocontrol of Verticillium wilt of cotton. Crop Protection 43: 231-240.

25. Dong W (2007) The soil moisture content research of the artificial forest and farm land in Xi.an area. Master thesis, Shaanxi Normal University.

26. Neidhardt FC, Bloch PL, Smith DF (1974) Culture medium for enterobacteria J Bacteriol 119: 736-747.

27. Udovic M, Drobne D, Lestan D (2013) An in vivo invertebrate bioassay of $\mathrm{Pb}$ $\mathrm{Zn}$ and Cd stabilization in contaminated soil. Chemosphere 92: 1105-1110.

28. Deng Z, Zhang R, Shi Y, Hu L, Tan H, et al. (2013) Enhancement of phytoremediation of $\mathrm{Cd}$ - and $\mathrm{Pb}$-contaminated soils by self-fusion of protoplasts from endophytic fungus Mucor sp. CBRF59. Chemosphere 91: 41-47.

29. Marklund S, Marklund G (1974) Involvement of the superoxide anion radical in the autoxidation of pyrogallol and a convenient assay for superoxide dismutase. Eur J Biochem 47: 469-474.

30. Bai XY, Dong YJ, Wang QH, Xu LL, Kong J, Liu S (2015) Effects of lead and nitric oxide on photosynthesis, antioxidative ability, and mineral element content of perennial ryegrass. Biologia Plantarum 59: 163-170.

31. Polle A, Otter T, Seifert F (1994) Apoplastic Peroxidases and Lignification in Needles of Norway Spruce (Picea abies L.). Plant Physiol 106: 53-60.

32. Schütze $E$, Kothe $E$ (2012) Heavy metal-resistant streptomycetes in soil: Bio-Geo interactions in metal-contaminated soils. Soil Biology. Berlin Heidelberg: Springer.

33. Khan MS, Zaidi A, Wani PA, Oves M (2009) Role of plant growth promoting rhizobacteria in the remediation of metal contaminated soils. Environmenta Chemistry Letters 7: 1-19.

34. Chen Q, Xue QH, Shen GH, Xue L, Duan CM, et al. (2010) Effect of actinomyces seed coating agent on cotton growth and drought resistance. Acta Agriculturae Boreali-Occidentails Sinica 19: 84-89.

35. Zhao J, Xue QH, Shen GH, Xue L, Duan JL, Wang DS (2012) Evaluation of Streptomyces spp. for biocontrol of gummy stem blight (Didymella bryoniae) and growth promotion of Cucumis melo L.. Biocontrol Science and Technology 22: 23-37.

36. Phieler R, Merten D, Roth M, Büchel G, Kothe E (2015) Phytoremediation using microbially mediated metal accumulation in Sorghum bicolor. Environ Sci Pollut Res 22: 19408-19416.

37. Duman F, Kar M (2015) Evaluation of effects of exposure conditions on the biological responses of Gammarus pulex exposed to cadmium. International Journal of Environmental Science and Technology 12: 437-444.

38. Zhang FQ, Wang YS, Lou ZP, Dong JD (2007) Effect of heavy metal stress on antioxidative enzymes and lipid peroxidation in leaves and roots of two mangrove plant seedlings (Kandelia candel and Bruguiera gymnorrhiza). Chemosphere 67: 44-50.

39. Miransari M (2011) Hyperaccumulators, arbuscular mycorrhizal fungi and stress of heavy metals. Biotechnol Adv 29: 645-653.

40. Lugtenberg B, Kamilova F (2009) Plant-growth-promoting rhizobacteria. Annu Rev Microbiol 63: 541-556.

41. Hall JL (2002) Cellular mechanisms for heavy metal detoxification and tolerance. J Exp Bot 53: 1-11

42. Jebara SH, Saadani O, Fatnassi IC, Chiboub M, Abdelkrim S, et al. (2015) Inoculation of Lens culinaris with Pb-resistant bacteria shows potential for phytostabilization. Environ Sci Pollut Res Int 22: 2537-2545.

43. Abou-Shanab RAI, Angle JS, Chaney RL (2006) Bacterial inoculants affecting nickel uptake by Alyssum murale from low, moderate and high $\mathrm{Ni}$ soils. Soil Biology and Biochemistry 38: 2882-2889.

44. Kothe E, Dimkpa C, Haferburg G, Schmidt A, Schütze E (2010) Streptomycetes heavy metal resistance: extracellular and intracellular mechanisms. Soil Heavy Metals 19: 225-235.

45. De Freitas JR, Germida JJ (1992) Growth promotion of winter whea by fluorescent pseudomonads under field conditions. Soil Biology and Biochemistry 24: 1137-1146.

46. Bauddh K, Singh RP (2012) Growth, tolerance efficiency and phytoremediation potential of Ricinus communis (L.) and Brassica juncea (L.) in salinity and drought affected cadmium contaminated soil. Ecotoxicol Environ Saf 85: 13-22. 